\title{
Board Competency Explanations for Differentiation in a Harmonisation Environment
}

\author{
Claus Holm (Corresponding author) \\ Department of Economics and Business, Aarhus University \\ FuglesangsAllé 4, DK-8210 Aarhus V, Denmark \\ Tel: 45-89-486-383 E-mail: hoc@asb.dk \\ Finn Schøler \\ Department of Economics and Business, Aarhus University \\ FuglesangsAllé 4, DK-8210 Aarhus V, Denmark \\ Tel: 45-89-488-999 E-mail: fsc@asb.dk
}

Received: November 23, 2011

Accepted: February 13, $2012 \quad$ Published: March 1, 2012

doi:10.5539/res.v4n1p52

URL: http://dx.doi.org/10.5539/res.v4n1p52

\begin{abstract}
Some companies decide to differentiate from others even though the regulatory establishments such as the European Union and IASB constantly strive to encourage comparability and the need for harmonisation of reporting behaviour and governance structures. Under the harmonization regime, decisions to differentiate become strategic in nature and are placed in the hands of the (supervisory) board. We examine the influence of the competency and background of supervisory board members on decisions to differentiate in reporting and governance structure. We use data from 100 listed Danish companies. We find that early IFRS implementation is related to board competency in the form of international experience, while corporate governance disclosure level is related to internationalisation, professional background in accounting/finance and gender diversity. We also find that differentiation through voluntary implementation of audit committees is related to international experience, while board decisions to abandon the Danish joint audit regime are unrelated to competency measures.
\end{abstract}

Keywords: Logistic regression, Resource dependency, Corporate governance, Internationalisation, Professional background, Diversity

\section{Introduction}

Some companies decide to differentiate from others even though the regulatory establishments such as the European Union and IASB constantly strive to encourage comparability and the need for harmonisation of reporting behaviour and governance structures. Under the harmonization regime, decisions to differentiate become strategic in nature and will be placed in the hands of the (supervisory) board. The individual board member has the potential to make valuable contributions to board decisions by providing unique perspectives on strategic issues (Castro, De La Concha, Gravel and Periñan, 2009; Gabrielsson, 2007; Van der Walt and Ingley, 2003) and can influence key outcomes (Brown, 2005; Erhardt, Werbel and Shrader, 2003; Ingley and Van der Walt, 2005). The principles of corporate governance (OECD, 2004, section VI) address the responsibilities of the board and link its strategic decisions to the background and competencies of board members (Gillespie, 2010). The EU Commission Recommendation on the role of board members advocates that the supervisory board should be composed of members who, as a whole, have the required diversity of knowledge, judgement and experience (European Commission, 2005). The presumption is that the nature and quality of strategic decisions are tied to the competency of the board members (Castro et al., 2009; Macus, 2008).

The purpose of our study is to examine the influence of competency and background of supervisory board members on decisions to differentiate in reporting and governance structure. We contribute to existing 
knowledge about optimal board compositions by considering possible explanations for the ability and willingness to make certain critical corporate decisions. Related studies have focused on explanations for other corporate decisions such as whether and how to export (Hessels and Terjesen, 2010), product and/or geographic diversification (Chen, Dyball and Wright, 2009) and choice of human resource management strategy (Buck, Filatotchev, Demina and Wright, 2003). We undertake an explorative study of the corporate governance codes' general recommendations for board member competencies in order to identify potential explanations for differentiation decisions. The competencies can be classified as related to internationalisation, professional background and diversity of the board members. We examine four specific instances of observed differentiation behaviour, namely two instances of disclosure behaviour: voluntary IFRS implementation and high level of CG disclosure, and two instances involving choice of governance structure: the abandonment of joint audit (change from two to one auditor) and the choice to use audit committees as part of the company governance structure.

Harmonisation of laws and standards is an international phenomenon that drives a number of the changes facing listed companies. Purposeful differentiation in a harmonisation context is not a contradiction. In contrast to the process of standardisation, harmonisation still allows diversity (Haller, 2002; McLeay, Neal and Tollington, 1999). It is generally recognised that companies possess different capacity for regulatory changes. Differences tend to materialise in two forms, namely: (1) differentiation from other companies by moving first and/or (2) differentiation from other companies by deciding on a higher level of corporate transparency or trustworthiness through governance structures. Differentiation behaviour is consistent with a resource-based perspective on competitive advantage as a driver for business strategy (Birkinshaw, Toulan and Arnold, 2001; Hessels and Terjesen, 2010; Lado, Boyd and Wright, 1992; Lieberman and Montgomery, 1998). Lado et al. (1992) suggest a resource-based perspective as an alternative to the more deterministic view derived from neoclassical economic theory. The latter type views competitive advantage as a consequence of market or industry pressures to which the company must respond via differentiation (e.g., Porter, 1998). The premise of the resource-based perspective is that company-specific competencies are potential rent-yielding strategic assets and these competencies "are consciously and systematically developed by the wilful choices and actions of the firm's strategic leaders," (Lado et al., 1992 , 78). Hence, we contend that the resource-based perspective can explain differences between reporting models and corporate governance arrangements. In the corporate governance literature, an alternative theoretical explanation for a corporate willingness to differentiate is found in agency theory (Coles, McWilliams and Sen, 2001; Li, 1994; Nicholson and Kiel, 2007). The prediction is that a reduction of asymmetric information through higher levels of corporate transparency or trustworthiness will lead to a reduction in the cost of capital (Botosan, Plumlee and Xie, 2004; Durnev, Errunza and Molchanov, 2009; Gietzmann and Ireland, 2005; Leuz and Verrecchia, 2000).

Our study is based on collected financial and corporate governance data for 100 listed Danish companies for 2004-2005. We observed four specific instances of differentiation in the dataset. Two of the differentiation decisions relate to reporting: (1) 15 percent were IFRS first movers (voluntary IFRS disclosure in the financial year 2004), (2) 23 percent displayed a high level of corporate governance disclosure. Two decisions are related to governance structures: (3) 55 percent abandoned the joint auditor system (traditionally germane to Denmark and France) for the year 2005, and (4) 12 percent of the companies had established an audit committee.

Our findings show that the impact of the three recommended types of board member competencies varies across these four differentiation decisions. We find that IFRS implementation is related to the board competency of having foreign board members on the supervisory board (internationalisation effect), while the other reporting decision (the choice of high corporate governance disclosure level) is related to board competency of all the three types identified in the corporate governance codes, i.e., internationalisation effect, professional background in accounting/finance and gender diversity. We find that governance structure involving the abandonment of joint audits is unrelated to competency measures. Finally we find that differentiation by introducing audit committees is mostly related to the internationalisation effect.

These observations suggest that company leaders in Denmark have sought a competitive advantage through differentiation in the part of the value chain directed toward the capital market. The globalisation of business has been accompanied by a harmonisation of disclosure requirements in terms of accounting rules (e.g., Baker and Barbu, 2007; Godfrey and Chalmers, 2007) and corporate governance recommendations (Chua, Eun and Lai, 2007; Luo, 2005). Hence, similar observations of differentiation would be expected in other countries, although the particular changes would be closely related to the particular governance setting of the individual country.

The remainder of the paper is structured as follows. In the next section we provide the motivation and literature review as basis for developing hypotheses on the relationship between differentiation decisions and the competencies of decision makers. In the subsequent sections we describe the applied methodology and analyse 
our findings pertaining to the differentiation decisions. We conclude the paper with a review and discussion of the contributions of our study.

\section{Motivation and literature review}

In this section we provide the motivation and literature review used as the basis for developing testable hypotheses. The section is divided in two subsections. In the first subsection, we introduce the context of harmonisation of financial reporting and corporate governance disclosure as a vantage point for company differentiation and we identify possible differentiation behaviour through critical corporate governance decisions in the context of regulatory changes. In the second subsection, we develop hypotheses related to the competencies of the potential decision makers at the supervisory boards when facing the critical corporate governance decisions.

\subsection{Differentiation in a harmonisation environment}

Differentiation through the choice of reporting and governance structure should be examined and understood in the context of the overall harmonisation environment. Godfrey and Chalmers $(2007,8)$ argue that global accounting standards are adopted in order to attract, or restrict the loss of, foreign investment in a national capital market. Baker and Barbu(2007) review over 200 research articles published between 1965 and 2004 dealing with international accounting harmonization. They pinpoint a number of important events on the accounting harmonization timeline (Baker and Barbu, 2007, 275). One of these events was the agreement in 1995 between the International Accounting Standards Committee (IASC) and the International Organization of Securities Commissions (IOSCO) to facilitate an international harmonisation of accounting standards. Another event was the mandatory requirement to use the IFRS standards in the European Union member states from 2005.

In an international comparison Chua et al. (2007) find that both corporate governance regime and the degree of capital market openness play a significant role in explaining corporate valuation. The reason is that restricted capital market regimes discourage international investments while open capital markets promote a more efficient risk sharing among international investors, which results in lower costs of capital and higher corporate valuation (Chua et al., 2007, 37). Luo(2005) stresses the importance of corporate accountability in the context of corporate governance for multinational companies: "Corporate accountability interrelates to corporate governance because it affects the credibility of information needed to support important activities, such as the creation and existence of enforceable contracts (e.g., manager compensation contracts contingent on performance results), the monitoring of managers by the board of directors and outside investors and regulators, and the exercise of investor rights as governed by securities laws," (Luo, 2005, 22).

Differentiation can be possible at the outset of (i.e., even before enactment of) new mandatory requirements or related to voluntary disclosures. In relation to new mandatory requirements companies may become "first movers" as suggested by prior research on early adopters of financial reporting requirements (e.g., Daske, 2006; Hoogendoorn, 2006; Renders and Gaeremynck, 2007). It could be that they are seeking to benefit from first mover advantages, while the "followers" are trying to benefit from "free rider" advantages (Lieberman and Montgomery, 1988). First movers will try to benefit from increased or maintained reputation in the capital market (as well as societal image effects). However, being first movers will have costs, i.e., direct, proprietary and liability costs (Healy and Palepu, 2001; Kalss, 2007).

In relation to voluntary disclosure the differentiation is a matter of certain companies deciding to disclose more financial information (e.g., Gray, Meek and Roberts, 1995; Renders and Gaeremynck, 2007) and/or non-financial information (e.g., Berglöf and Pajuste, 2005; Eng and Mak, 2003) than other companies. Paradoxically, the companies are trying to be exceptional by making reporting decisions which make them similar in a global environment. Hence, this is a relative gesture on the part of internationally oriented compared to nationally oriented companies. However, in an international context these companies are benchmarking at an accepted (presumably higher) level (Aisbitt, 2006; Buckley and Casson, 2009; Haxhi and Van Ees, 2010).

In this study we examine four specific instances of observed differentiation behaviour, namely two instances of disclosure behaviour: voluntary IFRS implementation and high level of CG disclosure and two instances involving choice of governance structure: the abandonment of joint audit (change from two to one auditor) and the choice to use an audit committee as part of the company governance structure.

\subsubsection{Voluntary IFRS implementation}

Voluntary IFRS implementation has been considered in prior studies (e.g., Daske and Gebhardt, 2006; Renders and Gaeremynck, 2007). The European Union decided to adopt the use of international accounting standards for consolidated accounts of publicly traded companies in the member states for financial years on or after January 
$1^{\text {st }} 2005$ (European Commission, 2002). Baker and Barbu(2007) describe this as a landmark event in terms of research on international accounting harmonization.

As indicated in figure 1, our sample of listed companies in Denmark had the option to voluntarily disclose the accounting information for the financial year 2004 in accordance with the IFRS/IAS standards or disclose in accordance with Danish regulations and standards. 15 of 100 companies in our dataset decided to be an IFRS first mover. This option was allowed by an executive order by the Danish Commerce and Companies Agency (DCCA) in January 2005 (DCCA, 2005). It became a mandatory requirement to disclose in accordance with IFRS/IAS for the financial year starting on or after January $1^{\text {st }} 2005$.

$<$ Insert Figure 1 about here $>$

\subsubsection{Corporate governance disclosure}

In prior studies the level of corporate governance disclosure has been considered as the appropriate choice variable (Berglöf and Pajuste, 2005; Eng and Mak, 2003; Holm and Schøler, 2010; Renders and Gaeremynck, 2007). The reason is that corporate governance disclosure is not an absolute but rather a relative issue, i.e., all companies disclose corporate governance related items to a certain extent. Hence, the reporting decision will be concerned with the level of disclosure (transparency level), i.e., differentiation behaviour equates a high disclosure level. 23 of 100 companies in our dataset are characterized in this way.

The first set of corporate governance recommendations for listed companies in Denmark was introduced for voluntary adoption in 2001. It was based on the Nørby Committee's report on corporate governance in Denmark (Nørby, 2001). (note 1) The objectives of the Nørby Committee's recommendations were as follows (Nørby, 2001, 13): (1) to make investment in Danish listed companies more attractive and to improve Danish companies' access to capital by attracting, for instance, foreign investors, (2) to inspire Danish companies and their supervisory and executive boards to meet the strategic challenges resulting from globalisation, thereby strengthening their competitive power, and (3) to propagate corporate governance in Danish companies by stimulating the debate on corporate governance.

In 2005, a revised set of corporate governance recommendations was approved (CSE, 2005). The CSE recommendations have since been incorporated into the disclosure requirements for Danish listed companies and apply to annual reports for financial years beginning on or after January $1^{\text {st }} 2006$ according to the "comply-or-explain" principle. In the context of level of corporate governance disclosure, it is important to note that the revision of CSE recommendations has involved several incremental steps.

First mover advantages have been discussed openly during the revision process. Initially a revised report from the Nørby Committee was issued in 2003. This was followed by a consultation process with the various stakeholders and led to a new set of recommendations published in June 2004. In order to include the latest recommendations by the European Commission on the role and independence of the directors and on remuneration (European Commission, 2004, 2005) as well as the introduction of the comply-or-explain principle, the final adoption of the corporate governance recommendations was postponed until 2005. It would be fair to assume that those companies targeting differential (best disclosure) behaviour would have been aware of the new recommendations by following the incremental steps of this revision process in the years 2003 to 2005 .

\subsubsection{Abandonment of joint audits (from two auditors to one)}

While joint audits are generally allowed in most European countries they seldom take place in practice (European Commission, 2001). In a few countries like France and Denmark, the joint audits have been institutionalized as part of the audit regulation (Francis, Richard and Vanstraelen, 2009; Piot, 2007). The tradition of the two auditor (joint auditor) system in Denmark was discussed before the implementation of the $4^{\text {th }}$, $7^{\text {th }}$ and $8^{\text {th }}$ accounting directive and it was not considered incompatible with the harmonization of the accounting and auditing regulation. Both before and after the implementation of the $4^{\text {th }}$ directive in the Accounting Act in 1981 and the $8^{\text {th }}$ directive in 1988 , the requirements for listed companies were that they should have two auditors and at least one auditor must be a state-authorized public accountant (note 2). This requirement was stated in the Company Act until 1988, but was transferred with the same wording to the revised 1988 Accounting Act (note 3). After a major revision of the Accounting Act in 2001, a voluntary joint auditor system was introduced, stipulating for listed companies that "at least one auditor must be a state-authorized public accountant" (DCCA, 2001). The regulatory body found that the companies would benefit from the abolishment of the mandatory two auditor system by 1) an expectedly lower audit cost, 2) an alignment of audit requirements with international competitors. The reason for the two auditor system had been to secure auditor independence and audit quality, but it was argued that new regulatory requirements now would supersede this raison d'être, e.g., through other 
mechanisms such as auditor rotation and institutional supervision to secure effective audit quality control systems in the audit firms. In order to leave the companies - and the auditors - time to implement the possibility of a move from two auditors to one, this option could first be chosen from the financial year 2005 (note 4), see figure 1. In our dataset 55 of 100 companies decided to abandon the joint auditor system at the earliest possible moment.

\subsubsection{Audit committees}

According to the EU recommendation on independence of management (2005), the appointment of sub-committees is intended to support the supervisory board's independence of the day-to-day management and increase efficiency. The EU recommendation presumes the appointment of nomination, remuneration and audit committees, but allows the companies to appoint less than three sub-committees. Prior studies have examined factors associated with the presence of audit committees (Carson, 2002; Chau and Leung, 2006). The function and purposes of board sub-committees such as audit, remuneration and nomination committees are naturally tied to the size of the board. Findings by Yermack (1996) were consistent with the notion that small boards of directors are more effective. These findings have been supported by later studies (e.g., Ahmed, Hossain and Adams, 2006; de Andres, Azofra and Lopez, 2005; Mak and Kusnadi, 2005). This suggests that the negative relationship between board size and firm value transcends different corporate governance systems (Mak and Kusnadi, 2005). Ahmed et al. (2006) found that earnings informativeness is negatively related to board size but is not related to the fraction of outside directors serving on the board. However, in a prior study of the Danish two-tier board setting, Rose (2005) found that board size does not affect the company performance (as proxied by Tobin's Q).

In its 2001 corporate governance recommendations the Nørby Committee stated that "most company boards are not so large that they require the establishment of board committees in order to be able to manage their tasks, and therefore appointments of board committees cannot be recommended in general." In figure 1 the possibility of a voluntary establishment of an audit committee is identified from the year 2004 in accordance with the initial revision of the Danish Corporate Governance Code in 2003 (see description of the incremental steps of the code revision process in the previous section). This relates to the way the sub-committees were described in the 2001 code where it was stated that "as a rule, if the board appoints a committee, this should only be done in order to prepare decisions that must be reached by all of the directors." In effect, the code did not allow an audit committee to function as a body that was independent of the supervisory board. In the 2005 code the decision to have an audit committee is still identified as a voluntary exception: "In companies with complex accounting and audit conditions, the supervisory board should consider establishing an audit committee to assist the supervisory board in accounting and audit matters" (CSE, 2005). The decision to establish an audit committee was made by 12 of the 100 companies in our dataset.

\subsection{Explaining differentiation by competencies of decision makers}

The willingness and the ability to make critical corporate governance decisions depend on the composition of the board and the resources of the company (Birkinshaw et al., 2001; Cantwell, Dunning and Lundan, 2010; Castro et al., 2009). It is asserted that the type of decision makers on the supervisory board influence the decisions made by listed companies. Corporate governance recommendations for supervisory boards tie strategic decisions and board member competencies (CSE, 2005; European Commission, 2005; OECD, 2004). Specifically, the recommendations for listed companies in Denmark identify international experience, professional background and diversity of the board as potential necessary competencies (CSE, 2005). While our examination of these recommendations is explorative in nature, the theories underlying the specific context we consider are "resource-based explanations" for the companies' ability to sustain competitive advantage by differentiating behaviour (Birkinshaw et al., 2001; Lado et al., 1992) and "agency theory/asymmetric information explanations" for the willingness to differentiate (Coles et al., 2001; Li, 1994; Nicholson and Kiel, 2007).

The importance of international experience of board members has been considered in prior studies (e.g., Luo, 2005; Oxelheim and Randøy, 2003; Casper Rose, 2006; Ruigrok, Peck and Tacheva, 2007). In a prior study of listed companies in Denmark, Rose (2006) found evidence supporting other studies showing that the international dimension of the board increases with the size of the company. A company with an internationally experienced board will benefit from the opportunity to reduce the information processing costs of globalisation "because more culturally diversified top management teams and corporate boards have greater processing capacity and can attend to more environmental cues and foreign liability problems" (Luo, 2005, 34). International experience can be accomplished by including native board members with international experience (such as board membership in foreign subsidiaries) or by including foreign board members on the supervisory 
board.

The composition of supervisory boards has been examined in a number of studies which have considered the importance of diversity (e.g., Erhardt et al., 2003; Haxhi and Van Ees, 2010; Kang, Cheng and Gray, 2007; Ruigrok et al., 2007; Terjesen, Sealy and Singh, 2009; Van der Walt and Ingley, 2003). Diversity in the composition of boards may include such factors as age, gender, ethnicity, culture, religion, constituency representation, independence, professional background, knowledge, technical skills and expertise, commercial and industry experience, career and life experience. Danish boards are actually characterized by having a relatively low degree of diversity (Casper Rose, 2006). The individual board member has the potential to make valuable contributions to board decisions by providing unique perspectives on strategic issues (Castro et al., 2009; Gabrielsson, 2007; Van der Walt and Ingley, 2003) and can influence key outcomes (Brown, 2005; Erhardt et al., 2003; Ingley and Van der Walt, 2005).

We explore the basis for differentiation through the choice of reporting and governance structure. In this study we examine four specific instances of differentiation decisions for each hypothesis. The study is explorative because we cannot predict the exact nature of the individual relationship between decisions and competency of decision makers. However, we choose to present the hypotheses in the positive form in order to align the predictions with the $\mathrm{CG}$ codes' general recommendations for board member competencies identified as international experience, professional background and diversity.

International experience effect (H1): The propensity to make differentiation decisions about reporting and governance structure in listed companies will be higher when the decision makers on the supervisory board include foreign board members or board members with international experience.

Professional background effect $(\mathrm{H} 2)$ : The propensity to make differentiation decisions about reporting and governance structure in listed companies will be higher when the decision makers on the supervisory board include board members with specific professional background (i.e., lawyer, accounting/finance experience, sales/marketing experience, specific industry experience).

Diversity effect (H3): The propensity to make differentiation decisions about reporting and governance structure in listed companies will be higher when the decision makers on the supervisory board have different backgrounds (diversity in gender, employee board participation and professional background).

\section{Methodology}

In this section we first describe the dataset and the variables applied. Second we present the models used to test the hypotheses developed in the previous section. Finally we provide some initial descriptive statistics.

\subsection{Dataset and variables}

The dataset contains corporate governance related attributes and size and performance indicators for the 100 most traded Danish companies listed on the Copenhagen Stock Exchange. Data was obtained from information in the 2004 annual reports, articles of association, and company websites. International guidelines such as the OECD Corporate Governance Guidelines (OECD, 2004) as well as the Danish Corporate Governance Code have inspired the selection of the corporate governance attributes (CSE, 2005). The corporate governance attributes are part of a larger Danish data set covering the development in different corporate governance issues during the period 2002 to 2005 (note 5). We collected information on 144 company specific issues of which 129 variables relate to corporate governance properties and 15 variables relate to company specific background such as size, performance, risk and industry (note 6).

The dependent variables in our study are the four corporate governance decisions identified in the previous section. The measures consist of four dummy variables: (1) IFRS implementation; coded as 1 if the company decided to adopt voluntary IFRS disclosure in the financial year 2004, and 0 otherwise, (2) CG disclosure level; coded as 1 if the corporate governance disclosure level (note 7) is located in the upper quartile for the 100 companies (high) and 0 otherwise (low), (3) From two auditors to one; coded as 1 if the company changed from two auditors to one in the financial year 2005, and 0 otherwise, and (4) Audit committee; coded as 1 if the company had established an audit committee, and 0 otherwise.

We examine the effect of our three hypotheses on the corporate governance decisions through independent variables such as international experience (two variables), professional background (four variables), board diversity (three variables), and company specific control variables (three variables). The following board member characteristics are measured as dummy variables: (1) International experience; coded as 1 if one or more members of the supervisory board have international experience such as board membership in foreign subsidiaries, and 0 otherwise (note 8), (2) Foreigner; coded as 1 if the company has one or more foreigners at the 
supervisory board, and 0 otherwise, (3) Accounting/finance experience; coded as 1 if one or more members of the supervisory board have professional accounting or finance experience, and 0 otherwise, (4) Sales/marketing experience; coded as 1 if one or more members of the supervisory board have professional sales or marketing experience, and 0 otherwise, (5) Industry experience; coded as 1 if one or more members of the supervisory board have specific industry experience related to the industry of the company, and 0 otherwise, (6) Lawyer; coded as 1 if the company has one or more lawyer(s) at the supervisory board, and 0 otherwise, (7) Diversity (gender); coded as 1 if the company has one or more women at the supervisory board, and 0 otherwise, (8) Diversity (employee); coded as 1 if the company has one or more employee representatives at the supervisory board, and 0 otherwise. We also constructed an alternative diversity variable used as independent variable: Diversity (composite); a composite measure using a nominal scale from 0 to 5 with one point for each board characteristic of the following: international experience, accounting/finance experience, sales/marketing experience, industry experience, and lawyer.

Measures of risk, performance and size of the board have been applied as control variables in a number of corporate governance studies due to the possible mitigating effects of these variables (e.g., Barontini and Caprio, 2006; Krivogorsky, 2006; Larcker, Richardson and Tuna, 2007). We have collected and examined 18 company specific control variables as possible candidates. We chose a representative for each of these, i.e, "Beta" as measure for risk and "ROIC three year average" as performance measure. "Board size" is strongly correlated with company size and also control for the potential for diversity.

\subsection{Models}

In order to examine the three overall hypotheses we use logistic regression models, i.e., one for each of the four differentiation decisions testing each hypothesis separately (resulting in 12 individual models). In addition, we formulated a reduced model for each decision with the most relevant variable identified in the initial analysis as predictor (resulting in four models). The models for the differentiation decisions all have the same structure, i.e., measuring the possible board member effects of international experience, professional background or diversity, and controlling for the same company specific control variables, see tables 4-7.

\subsection{Descriptive statistics}

We provide descriptive statistics for the sample in tables 1, 2 and 3. First, we notice an uneven distribution of supervisory board composition across the 100 listed companies. Because the board member characteristics are coded as dummy variables we only provide the actual frequencies in table 1 . In relation to the international dimension present at the supervisory boards more companies have board members with international experience than not (63 vs. 37) while a minority has foreign representation at the board (32 vs. 68). Women are part of the supervisory boards in 29 of the 100 companies. In terms of professional background, the dominant feature is industry experience ( 74 vs. 26 ) and accounting/finance experience ( 57 vs. 43 ). We find representation by lawyers (19 vs. 81) to be rather exceptional, while about one third of the companies have board members with sales/marketing experience (34 vs. 66).

$<$ Insert Tables 1, 2 and 3 about here $>$

The frequency distribution presented in table 2 shows the variation in the differentiation decisions as measured by the dummy variables, i.e., indicating the possibility for the companies to differentiate through critical decisions. The decision to voluntarily adopt IFRS for the financial year 2004 was made by 15 of 100 companies. The choice of a high level of corporate governance disclosure is really a forced distribution. We have chosen to distinguish between the upper quartile and the remaining population, i.e., forcing a distribution of differentiation at 23 vs. 77 . At a very early stage 55 of 100 companies announced that they would change from a two auditor system to a single auditor system in 2005 , while only 12 companies have established audit committees, see also figure 1.

Finally, we turn to the distribution of the company specific control variables. The means and distributions of the three control variables for risk, performance and board size are shown in table 3 . The average board size for the listed companies is fairly low by international standard (mean 7.71) and rather homogenous in size (std.dev. 2.48), although the range extends from two to 18 board members including employee representatives (note 9).

\section{Analyses}

In this section we examine the hypothesized relationships between instances of differentiation decisions and decision maker competencies. We take two explorative steps starting with a more detailed examination of the three hypotheses followed by further analyses based on all effects models. 


\subsection{Hypotheses tests}

The hypothesised competency effects may coincide with the background factors for a particular company. Therefore our main findings are presented in the form of models controlling for such factors. The first explorative step is to examine the three hypotheses one by one. In table 4, we show the results for the models testing internationalisation effects (H1). The panels A-D in table 4 each reflect one of the four differentiation decisions. Overall, three of the four logistic regression models exploring international effects are significant. We find that having foreign board members affects the two reporting decisions of voluntary IFRS implementation and high corporate governance disclosure level (both significant at the 5 percent level). In relation to governance structure, the decision to abandon joint audits is not affected by international experience, while the decision to have an audit committee is related to having foreign board participation (significant at the 5 percent level) (note 10). Our findings support $\mathrm{H} 1$ when using the foreigner measure, but the only additional impact of the international experience measure is on higher corporate governance disclosure level (significant at the 5 percent level). In relation to the decision to abandon joint audits we note that negative directions are captured in the parameter estimates for international experience and for board size (board size is positively correlated with foreigners on the board).

$<$ Insert Table 4 about here $>$

Hence, our hypothesis H1 is supported for the differentiation decision about voluntary IFRS implementation. The odds ratio (exponential to the parameter estimate) for the competency measured by the foreigner variable is 4.57, i.e., suggesting that it is 4.57 as likely to decide on IFRS implementation when the supervisory board includes foreigners, than if not. The three year average on ROIC is negatively related to the decision (significant at the 5 percent level). This suggests that voluntary IFRS implementation was related to low performance when using accounting measures (while not tabulated, this finding is supported using one year ROIC for the year of change and also using alternative performance measures). The same is not true for the other reporting decision included in our study. Corporate governance disclosure level is partly explained by board size (and company size), but not performance. This differentiation decision is significantly related to larger companies as well as to the internationalisation effect. In relation to the audit committee decision, we find that both board size and risk (beta) affects the differentiation behaviour.

Our findings support claims made in prior studies regarding foreign board members' possible influence on reporting and governance structure (Oxelheim and Randøy, 2003; Ruigrok et al., 2007; Van der Walt and Ingley, 2003). Oxelheim and Randøy examined the importance of outsider Anglo-American board memberships in a Scandinavian setting (listed companies in Norway and Sweden). They suggest that foreign board membership "enhances the international orientation of the firm, and serves as a catalyst for further globalization of a corporation" (Oxelheim and Randøy, 2003, 2388). The globalisation of the capital markets will affect the reporting behaviour of companies: "at a minimum, big investors are demanding international standards of corporate behaviour, accounting clarity, and disclosure" (Li, 1994, 366-367).

We provide an overview of the models testing the professional background effects $(\mathrm{H} 2)$ in table 5 . We find support for two of the four models (both significant at the 0.1 percent level). Although the model for IFRS implementation is not significant, the professional background in sales/marketing is marginally significant at the 10 percent level. The odds ratio suggests that it is 2.87 as likely to implement IFRS when the competencies of the board include prior sales/marketing experience, than if not. The two significant models relate to corporate governance disclosure and the audit committee differentiation decisions. The corporate governance disclosure level is significantly affected by professional accounting/finance background experience. It is 4.12 as likely to have a high disclosure level when having accounting/finance competence present in the supervisory board, than if not. We find no evidence supporting a link between the professional background variables and audit committee choice. Instead this differentiation decision is entirely driven by risk, (negative) performance and board size. The "two auditors to one" model clearly identifies sales/marketing experience as a positive factor in explaining the abandonment of joint audits (odds ratio of 2.30 at the 10 percent significance level). Here the board size is negatively related to the differentiation decision (significant at the 10 percent level), i.e., small rather than large boards prefer to differentiate.

Given the fact that standard setters have pointed to professional background as a valuable component in supervisory board composition (CSE, 2005; OECD, 2004), it is notable that our findings do not in its entirety support their importance and influence on reporting and governance structure. Chen et al. examined strategic diversification decisions in Australian companies and found that industry experience was a relevant board background, i.e., the proportion of interlocking directors with extra-industry ties on the board had a significant 
and positive impact on the level of diversification (Chen et al., 2009, 218). However, the importance of industry experience is not supported for any of the strategic decisions considered in our study. As regards the importance of professional background, one exception is our finding of a significant relationship between companies with board members with accounting/finance background and the choice of a high level of corporate governance reporting. This could be interpreted as support for influence of board members predisposed toward high quality reporting based on expertise in assessing capital market risks and rewards (e.g., Healy and Palepu, 2001; Kalss, 2007).

\section{$<$ Insert Table 5 about here $>$}

In table 6, we show our findings related to diversity effects (H3). We find support for this hypothesis for two of the four differentiation decisions, i.e., diversity provides possible explanations for differentiation through corporate governance disclosure and audit committee choice (both models significant at the 0.1 percent level). Diversity is measured in three different ways. The measure involving gender (women present or not) is significant at the 5 percent level for the corporate governance disclosure, see table 6 , panel B. The odds ratio suggests that it is 3.73 as likely to choose a high corporate governance disclosure level when there is one or more female members on the board. In their extensive review of studies of women on corporate boards, Terjesen et al. argues that it is crucial to acknowledge women as part of the talent pool for board positions while also recognizing "a continual call for research that proves the added value of women on corporate boards" (Terjesen et al., 2009, 333). Female representation on the board does not necessarily equate a diverse influence on corporate decision making because predominant masculine behaviour may prevail (Erhardt et al., 2003; Kang et al., 2007; Sheridan and Milgate, 2005). In this context, it is noticeable that our findings suggest that female representation on boards seems to increase the board's willingness and ability to choose a high level of corporate governance disclosure. Diversity is also proxied by the composite measure (significant at the 0.1 percent level for the corporate governance decision). Recall that the composite measure is a cumulative measure for the five experience types including international, accounting/finance, sales/marketing, industry, and lawyer. The more diversified in terms of professional background, the larger the propensity to provide high level of corporate governance disclosure (odds ratio of 2.38). The importance of diversity in board composition as a dominant influence in making strategic decisions is consistent with the findings of Chen et al. (2009) on corporate diversification decisions. We also notice that this model is explained by board size, while the only diversity measure which is significantly correlated by board size is the employee measure (untabulated). Our finding of a positive relationship between board size and information level is not consistent with findings in prior studies (e.g., Ahmed et al., 2006; Mak and Kusnadi, 2005), although it can be interpreted as consistent with predictions of resource dependency theory, i.e., the availability of necessary expertise for strategic decision making (Chen et al., 2009; Hessels and Terjesen, 2010).

The differentiation through audit committees is very similar to the governance disclosure model, although the gender effect is not present, see table 6, panel $\mathrm{D}$. We also notice that the composite measure is significant at the 5 percent level. Because the composite measure is a cumulative measure for the five experience types, this provides an insight into the context of the internationalisation effect (which was present, see table 4, panel D) and the professional background effect (which was not, see table 5, panel D). The internationalisation effect seems to be important for Danish companies' harmonization of reporting and governance structures on the international capital market. Our finding of a diversity effect for the choice of audit committees is consistent with prior findings on the international orientation of Danish companies (Holm and Schøler, 2010; Casper Rose, 2006). However, the diversity of the boards cannot explain the companies' propensity for early IFRS implementation (table 6, panel A) or change from two auditors to one (table 6, panel C).

$<$ Insert Table 6 about here>

\subsection{Tests of all effects models}

We provide an overview of the second explorative step in testing the three hypothesised competency effects in table 7. The purpose is to examine the robustness of the models for the differentiation decisions and test for possible simultaneous effects of international experience, professional background and diversity. Here we use results from the first step to specify reduced logistic regression models. In order not to over-specify the models, we include one independent variable for each competency effect, if such an effect was detected in the first step of the analysis. Whenever there is a choice of variables for the effect, we have based the choice on the size of significance level and odds ratio indicated in the first models (see tables 4 to 6).

In the tests of the all effects models, we obtain significant overall models for all differentiation decisions except the abandonment of joint audits decision. The IFRS implementation is affected by the internationalisation effect 
as measured by the foreigner variable, see table 7 , panel A. In contrast to the individual model for professional background, the sales/marketing effect is not significant in the all effects model. The explanatory effect of poor performance (ROIC) is also present. The model chi-square is 14.2, which is close to the comparable test statistic for the model specifying only internationalisation effects (see table 4). The second reporting decision involving corporate governance disclosure is affected by all three competency effects measured as international experience, accounting/finance experience and gender diversity, respectively, see table 7, panel B. In the all effects model, the board size is also a significant explanatory variable at the 0.1 percent level. The call for board diversity seems to be highly relevant for the corporate governance disclosure level, i.e., the amalgamation of these findings are consistent with predictions from the resource dependency perspective (Birkinshaw et al., 2001; Hessels and Terjesen, 2010; Lado et al., 1992; Lieberman and Montgomery, 1998).

Consistent with the findings resulting from the individual models, only the governance structure differentiation model for audit committees is significant in the all effects test, see table 7, panels $\mathrm{C}$ and $\mathrm{D}$. In this model the gender diversity is marginally significant at the 10 percent level, while the internationalisation effect is significant at the 5 percent level. The odds ratio for the foreigner variable is 44.8 . Therefore it seems reasonable to surmise that foreign board members inspire the choice of audit committees as suggested in the previous subsection. Risk and board size are both significant explanatory variables in this model, In effect, the positive relationships suggest a risk-based acknowledgement of the extended need for supervisory control (beta significant at the 5 percent level) and also an ability to form meaningful subcommittees - such as an audit committee - as a subset of the full supervisory board (board size significant at the 1 percent level).

$<$ Insert Table 7 about here $>$

\section{Conclusion and Discussion}

Some company leaders decide to differentiate their companies from others even though the regulatory establishments such as the European Union and IASB strive to encourage comparability and the need for harmonisation of reporting behaviour and governance structures. Under the harmonization regime, decisions to differentiate become strategic in nature and will be placed in the hands of the (supervisory) board. We are able to observe that some company leaders change their reporting behaviour and corporate governance features before and to a higher extent than comparable companies. Corporate governance recommendations for (supervisory) boards tie strategic decisions with board member competencies such as international experience, professional background and diversity of the board.

We identify four instances of strategic differentiation observed among Danish listed companies in 2004-2005. Such differentiation behaviour is predicted by theory, i.e., we consider "resource-based explanations" for the companies' ability to sustain competitive advantage by differentiating behaviour and "agency theory/asymmetric information explanations" for the willingness to differentiate (Birkinshaw et al., 2001; Hessels and Terjesen, 2010; Lado et al., 1992; Lieberman and Montgomery, 1998). Related studies have focused on explanations for other corporate decisions such as whether and how to export (Hessels and Terjesen, 2010), product and/or geographic diversification (Chen et al., 2009) and choice of human resource management strategy (Buck et al., 2003). Two of the differentiation decisions in our study are related to reporting and two are related to governance structures. For the first reporting decision we find that the IFRS first mover decision(voluntary IFRS disclosure in the financial year 2004) is related to board competency indicated by having foreigners on the supervisory board (internationalisation effect), i.e., H1 is supported for this differentiation decision. Our findings are consistent with prior studies regarding foreign board members' possible influence on reporting and governance structure (Oxelheim and Randøy, 2003; Ruigrok et al., 2007; Van der Walt and Ingley, 2003). It is noticeable, that we do not find support for the importance of different types of professional background even though professional expertise is strongly promoted by standard setters as a preferable component in the composition of supervisory boards (CSE, 2005; OECD, 2004). The second reporting decision is the choice of high corporate governance disclosure level. This differentiation decision is related to board competency of all the three types identified in the corporate governance codes, i.e., H1 (international experience), H2 (accounting background) and H3 (gender diversity) are all supported for this differentiation decision. One of our main findings is that the call for board diversity seems to be highly relevant for the corporate governance disclosure level. This also supports the resource dependency perspective in relation to the ability and willingness to strengthen corporate governance reporting (Birkinshaw et al., 2001; Eng and Mak, 2003; Hessels and Terjesen, 2010).

The remaining differentiation decisions in our study are related to governance structures. We find that governance structure involving the abandonment of joint audits is unrelated to competency measures in every model we tested. In contrast we find support for the international experience effect (H1) and marginal support for 
the diversity effect (H3) when considering differentiation by introducing audit committees in the governance structure. The internationalisation effect seems to be important for Danish companies' harmonization of reporting and governance structures on the international capital market. Our finding of a diversity effect for the choice of audit committees is consistent with findings in prior studies on the international orientation of Danish companies (Holm and Schøler, 2010; Casper Rose, 2006).

We contribute to existing knowledge about optimal board composition by providing explanations for the ability and willingness to make certain critical corporate decisions. The explanations should be considered in the light of our purposive exploratory study of the general recommendations for board member competencies set out in the corporate governance codes. These observations suggest that company leaders in Denmark have sought a competitive advantage through differentiation in the part of the value chain directed toward the capital market. The globalisation of business has been accompanied by a harmonisation of disclosure requirements in terms of accounting rules (e.g., Baker and Barbu, 2007; Godfrey and Chalmers, 2007) and corporate governance recommendations (Chua et al., 2007; Luo, 2005). Hence, similar observations of differentiation can be expected in other countries, although the particular changes would be closely related to the particular governance setting of the individual country.

The limitations of our study are related to the explorative nature of the research, the chosen methodology and the measures applied. The specific needs for supervision and control in individual companies can be explored in much more detail through a case by case basis, while our archival approach provides insight to the fundamental relationships between relevant constructs. The corporate governance codes' general recommendations for board member competencies may be more or less relevant depending on the nature and complexity of the individual business. Our choice of explanatory variables such as international experience, professional background and diversity only proxies for board member experience and expertise. The relevance of formal background and the actual influence on decisions is implied in our research. Therefore, we only provide restricted insight into the effect of the individual board members on actual decision and consensus making processes in the board room. Another limitation of our study is the underlying endogeneity of the factors considered. We have cast our predictions implying causality between board competencies and strategic decision making. However, an element of self-selection of board members would be foreseeable, i.e., the company would strive to obtain a composition of board members with the diversity and expertise needed to make the board capable of meeting the strategic challenges of the company.

Our findings have several implications for future research and practice. Future research into the qualitative aspects of board room decision making is pertinent. The individual competencies of board members and the compositions of supervisory boards are relevant and important factors for our understanding of corporate decision making. The practical implications of our study are related to regulatory requirements for board composition and competencies and to actual board composition in context specific scenarios for listed companies. Regulators, shareholders and current as well as prospective board members should acknowledge that the need for diversity in board member competencies should match the particular variety of critical strategic decisions facing the individual company.

\section{References}

Ahmed, K., Hossain, M. \& Adams, M. B. (2006). The Effects of Board Composition and Board Size on the Informativeness of Annual Accounting Earnings. Corporate Governance, 14(5), 418-431. http://dx.doi.org/10.11 11/j.1467-8683.2006.00515.x

Aisbitt, T. (2006). Assessing the Effect of the Transition to IFRS on Equity: The Case of the FTSE 100. Accounting in Europe, 3, 117-133. http://dx.doi.org/10.1080/09638180600920293

Baker, C. R. \& Barbu, E. M. (2007). Trends in Research on International Accounting Harmonization. The International Journal of Accounting, 42(3), 272-272. http://dx.doi.org/10.1016/j.intacc.2007.06.003

Barontini, R. \& Caprio, L. (2006). The Effect of Family Control on Firm Value and Performance: Evidence from Continental Europe. European Financial Management, 12(5), 689-723. http://dx.doi.org/10.1111/j.1468-036X.20 06.00273.x

Berglöf, F. E. \& Pajuste, A. (2005). What do Firms Disclose and Why? Enforcing Corporate Governance and Transparency in Central and Eastern Europe. Oxford Review of Economic Policy, 21(2), 178-197. http://dx.doi.o rg/10.1093/oxrep/gri011

Birkinshaw, J., Toulan, O. \& Arnold, D. (2001). Global Account Management in Multinational Corporations: Theory and Evidence. Journal of International Business Studies, 32(2), 231-248. http://dx.doi.org/10.1057/palgra 
ve.jibs. 8490950

Botosan, C. A., Plumlee, M. A. \& Xie, Y. (2004). The Role of Information Precision in Determining the Cost of Equity Capital. Review of Accounting Studies, 9(2-3), 233-259. http://dx.doi.org/10.1023/B:RAST.000002818 8.71604.0a

Brown, W. A. (2005). Exploring the Association between Board and Organizational Performance in Nonprofit Organizations. Nonprofit Management and Leadership, 15(3), 317-339. http://dx.doi.org/10.1002/nml.71

Buck, T., Filatotchev, I., Demina, N. \& Wright, M. (2003). Insider Ownership, Human Resource Strategies and Performance in a Transition Economy. Journal of International Business Studies, 34(6), 530-549. http://dx.doi.or $\mathrm{g} / 10.1057 /$ palgrave.jibs. 8400065

Buckley, P. J. \& Casson, M. C. (2009). The Internalisation Theory of the Multinational Enterprise: A Review of the Progress of a Research Agenda after 30 Years. Journal of International Business Studies, 40(9), 1563-1580. http://dx.doi.org/10.1057/jibs.2009.49

Cantwell, J., Dunning, J. H. \& Lundan, S. M. (2010). An Evolutionary Approach to Understanding International Business Activity: The Co-evolution of MNEs and the Institutional Environment. Journal of International Business Studies, 41(4), 567-586. http://dx.doi.org/10.1057/jibs.2009.95

Carson, E. (2002). Factors Associated with the Development of Board Sub-committees. Corporate Governance: An International Review, 10(1), 4-18. http://dx.doi.org/10.1111/1467-8683.00263

Castro, C. B., De La Concha, M. D., Gravel, J. V. \& Periñan, V. (2009). Does the Team Leverage the Board's Decisions? Corporate Governance : An International Review, 17(6), 744-761. http://dx.doi.org/10.1111/j.14678683.2009.00772.x

Chau, G. \& Leung, P. (2006). The impact of board composition and family ownership on audit committee formation: Evidence from Hong Kong. Journal of International Accounting, Auditing and Taxation, 15(1), 1-15. http://dx.doi.org/10.1016/j.intaccaudtax.2006.01.001

Chen, R., Dyball, M. C. \& Wright, S. (2009). The Link Between Board Composition and Corporate Diversification in Australian Corporations. Corporate Governance: An International Review, 17(2), 208-223. http://dx.doi.org/10.1111/j.1467-8683.2009.00734.x

Chua, C., Tze, Eun, C., S. \& Lai, S. (2007). Corporate Valuation Around the World: The Effects of Governance, Growth, and Openness. Journal of Banking \& Finance, 31(1), 35-35. http://dx.doi.org/10.1016/j.jbankfin.2006.0 2.002

Coles, J. W., McWilliams, V. B. \& Sen, N. (2001). An examination of the relationship of governance mechanisms to performance. Journal of Management, 27(1), 23-50. http://dx.doi.org/10.1177/014920630102700 102

CSE. (2005). Corporate Governance Recommendations: Copenhagen Stock Exchange Committee on Corporate Governance.

Daske, H. (2006). Economic Benefits of Adopting IFRS or US-GAAP - Have the Expected Cost of Equity Capital Really Decreased? Journal of Business Finance and Accounting, 33(3-4), 329-373. http://dx.doi.org/10.1 111/j.1468-5957.2006.00611.x

Daske, H. \& Gebhardt, G. (2006). International financial reporting standards and experts' perceptions of disclosure quality. Abacus, 42(3-4), 461-461. http://dx.doi.org/10.1111/j.1467-6281.2006.00211.x

DCCA. (2001). Danish Act no. 448 of 7 June, the Danish Commerce and Companies Agency (DCCA), The Danish Financial Statements Act.

DCCA. (2005). Executive order 24 of January 11, the Danish Commerce and Companies Agency (DCCA), Bekendtgørelse om mulighed for at anvende internationale regnskabsstandarder (IFRS) før 1. January 2005 for virksomheder omfattet af årsregnskabsloven.

de Andres, P., Azofra, V. \& Lopez, F. (2005). Corporate Boards in OECD Countries: Size, Composition, Functioning and Effectiveness. Corporate Governance, 13(2), 197-210. http://dx.doi.org/10.1111/j.1467-8683.20 05.00418.x

Durnev, A., Errunza, V. \& Molchanov, A. (2009). Property Rights Protection, Corporate Transparency, and Growth. Journal of International Business Studies, 40(9), 1533-1562. http://dx.doi.org/10.1057/jibs.2009.58

Eng, L. L. \& Mak, Y. T. (2003). Corporate Governance and Voluntary Disclosure. Journal of Accounting and 
Public Policy, 22(4), 325-345. http://dx.doi.org/10.1016/S0278-4254(03)00037-1

Erhardt, N. L., Werbel, J. D. \& Shrader, C. B. (2003). Board of Director Diversity and Firm Financial Performance. Corporate Governance: An International Review, 11(2), 102-112. http://dx.doi.org/10.1111/1467-8 683.00011

European Commission. (2001). Study on Systems of Civil Liability of Statutory Auditors in the Context of a Single Market for Auditing services in the European Union. [Online] Available: http://ec.europa.eu/internal_ma rket/auditing/docs/liability/auditliability_en.pdf

European Commission. (2002). Regulation (EC) No 1606/2002 of the European Parliament and of the Council of 19 July 2002 on the Application of International Accounting Standards.

European Commission. (2004). Commission Recommendation of 14 December 2004 fostering an appropriate regime for the remuneration of directors of listed companies (2004/913/EC).

European Commission. (2005). Commission Recommendation of 15 February 2005 on the role of non-executive or supervisory directors of listed companies and on the committees of the (supervisory) board (2005/162/EC).

Francis, J. R., Richard, C. \& Vanstraelen, A. (2009). Assessing France's Joint Audit Requirement: Are Two Heads Better than One? Auditing, 28(2), 35-63. http://dx.doi.org/10.2308/aud.2009.28.2.35

Gabrielsson, J. (2007). Correlates of Board Empowerment in Small Companies. Entrepreneurship Theory and Practice, 31(5), 687-711. http://dx.doi.org/10.1111/j.1540-6520.2007.00195.x

Gietzmann, M. \& Ireland, J. (2005). Cost of Capital, Strategic Disclosures and Accounting Choice. Journal of Business Finance and Accounting, 32(3-4), 599-634. http://dx.doi.org/10.1111/j.0306-686X.2005.00606.x

Gillespie, M. H. (2010). How to Build the Right Board: Composition and Development. NACD Directorship, 36(1), 54-58.

Godfrey, J. M. \& Chalmers, K. (2007). Globalisation of Accounting Standards: An Introduction. In J. M. a. C. Godfrey, K. (Ed.), Globalisation of Accounting Standards (pp. 1-14). Cheltenham, UK: Edward Elgar.

Gray, S., J., Meek, G. K. \& Roberts, C., B. (1995). International Capital Market Pressures and Voluntary Annual Report Disclosures by U.S. and U.K. Multinationals. Journal of International Financial Management and Accounting, 6(1), 43-69. http://dx.doi.org/10.1111/j.1467-646X.1995.tb00049.x

Haller, A. (2002). Financial Accounting Developments in the European Union: Past Events and Future Prospects. European Accounting Review, 11(1), 153-190. http://dx.doi.org/10.1080/09638180220124770

Haxhi, I. \& Van Ees, H. (2010). Explaining Diversity in the Worldwide Diffusion of Codes of Good Governance. Journal of International Business Studies, 41(4), 710-726. http://dx.doi.org/10.1057/jibs.2009.39

Healy, P. M. \& Palepu, K. G. (2001). Information Asymmetry, Corporate Disclosure, and the Capital Markets: A Review of the Empirical Disclosure Literature. Journal of Accounting and Economics, 31(1-3), 405-440. http://dx.doi.org/10.1016/S0165-4101(01)00018-0

Hessels, J. \& Terjesen, S. (2010). Resource dependency and institutional theory perspectives on direct and indirect export choices. Small Business Economics, 34(2), 203-220. http://dx.doi.org/10.1007/s11187-008-91564

Holm, C. \& Schøler, F. (2010). Reduction of Asymmetric Information Through Corporate Governance Mechanisms - The Importance of Ownership Dispersion and Exposure toward the International Capital Market. Corporate Governance : An International Review, 18(1), 32-47. http://dx.doi.org/10.1111/j.1467-8683.2009.0077 7.x

Hoogendoorn, M. (2006). International Accounting Regulation and IFRS Implementation in Europe and Beyond -- Experiences with First-time Adoption in Europe. Accounting in Europe, 3, 23-26. http://dx.doi.org/10.1080/09 638180600920087

Ingley, C. \& Van der Walt, N. (2005). Do Board Processes Influence Director and Board Performance? Statutory and performance implications. Corporate Governance, 13(5), 632-653. http://dx.doi.org/10.1111/j.1467-8683.20 05.00456.x

Kalss, S. (2007). Recent developments in liability for nondisclosure of capital market information. International Review of Law and Economics, 27(1), 70-70. http://dx.doi.org/10.1016/j.irle.2007.04.005

Kang, H., Cheng, M. \& Gray, S. J. (2007). Corporate Governance and Board Composition: Diversity and Independence of Australian Boards. Corporate Governance, 15(2), 194-194. http://dx.doi.org/10.1111/j.1467-86 


\subsubsection{4.x}

Krivogorsky, V. (2006). Ownership, Board Structure, and Performance in Continental Europe. International Journal of Accounting, 41(2), 176-198. http://dx.doi.org/10.1016/j.intacc.2006.04.002

Lado, A. A., Boyd, N. G. \& Wright, P. (1992). A Competency-Based Model of Sustainable Competitive Advantage: Toward a Conceptual Integration. Journal of Management, 18(1), 77. http://dx.doi.org/10.1177/0149 20639201800106

Larcker, D. F., Richardson, S. A. \& Tuna, I. (2007). Corporate Governance, Accounting Outcomes, and Organizational Performance. Accounting Review, 82(4), 963-1009. http://dx.doi.org/10.2308/accr.2007.82.4.963

Leuz, C. \& Verrecchia, R. E. (2000). The Economic Consequences of Increased Disclosure. Journal of Accounting Research, 38, 91-124. http://dx.doi.org/10.2307/2672910

Li, J. (1994). Ownership Structure and Board Composition: A Multi-Country Test of Agency Theory Predictions. Managerial and Decision Economics, 15(4), 359-368. http://dx.doi.org/10.1002/mde.4090150409

Lieberman, M. B. \& Montgomery, D. B. (1988). First-Mover Advantages. Strategic Management Journal, 9 , 41-58. http://dx.doi.org/10.1002/smj.4250090706

Lieberman, M. B. \& Montgomery, D. B. (1998). First-Mover (Dis)Advantages: Retrospective and Link with the Resource-Based View. Strategic Management Journal, 19(12), 1111-1125. http://dx.doi.org/10.1002/(SICI)10970266(1998120)19:12<1111::AID-SMJ21>3.0.CO;2-W

Luo, Y. (2005). How does Globalization affect Corporate Governance and Accountability? A Perspective from MNEs. Journal of International Management, 11(1), 19-41. http://dx.doi.org/10.1016/j.intman.2004.11.003

Macus, M. (2008). Board Capability: An Interactions Perspective on Boards of Directors and Firm Performance. International Studies of Management and Organization, 38(3), 98-98. http://dx.doi.org/10.2753/IMO0020-88253 80304

Mak, Y. T. \& Kusnadi, Y. (2005). Size Really Matters: Further Evidence on the Negative Relationship between Board Size and Firm Value. Pacific-Basin Finance Journal, 13(3), 301-318. http://dx.doi.org/10.1016/j.pacfin.20 04.09.002

McLeay, S., Neal, D. \& Tollington, T. (1999). International Standardisation and Harmonisation: A New Measurement Technique. Journal of International Financial Management and Accounting, 10(1), 42-70. http://d x.doi.org/10.1111/1467-646X.00042

Nicholson, G. J. \& Kiel, G. C. (2007). Can Directors Impact Performance? A Case-based Test of Three Theories of Corporate Governance. Corporate Governance: An International Review, 15(4), 585-608. http://dx.doi.org/10. 1111/j.1467-8683.2007.00590.x

Nørby. (2001). The Nørby Committee's report on Corporate Governance in Denmark.

OECD. (2004). Principles of Corporate Governance OECD, Paris.

Oxelheim, L. \& Randøy, T. (2003). The Impact of Foreign Board Membership on Firm Value. Journal of Banking and Finance, 27(12), 2369-2392. http://dx.doi.org/10.1016/S0378-4266(02)00395-3

Piot, C. (2007). Auditor Concentration in a Joint-auditing Environment: The French Market 1997-2003. Managerial Auditing Journal, 22(2), 161-177. http://dx.doi.org/10.1108/02686900710718663

Porter, M. E. (1998). Competitive Advantage: Creating and Sustaining Superior Performance. New York, NY: The Free Press.

Renders, A. \& Gaeremynck, A. (2007). The Impact of Legal and Voluntary Investor Protection on the Early Adoption of International Financial Reporting Standards (IFRS). De Economist, 155(1), 49-72. http://dx.doi.org /10.1007/s10645-006-9041-y

Rose, C. (2005). The Composition of Semi-Two-Tier Corporate Boards and Firm Performance. Corporate Governance: An International Review, 13(5), 691-701. http://dx.doi.org/10.1111/j.1467-8683.2005.00460.x

Rose, C. (2006). Board Composition and Corporate Governance - A Multivariate Analysis of Listed Danish Firms. European Journal of Law and Economics, 21(2), 113-127. http://dx.doi.org/10.1007/s10657-006-6645-2

Ruigrok, W., Peck, S. and Tacheva, S. (2007). Nationality and Gender Diversity on Swiss Corporate Boards. Corporate Governance, 15(4), 546-557. http://dx.doi.org/10.1111/j.1467-8683.2007.00587.x

Sheridan, A. \& Milgate, G. (2005). Accessing Board Positions: A Comparison of Female and Male Board 
Members' Views. Corporate Governance: An International Review, 13(6), 847-847. http://dx.doi.org/10.1111/j.1 467-8683.2005.00475.x

Terjesen, S., Sealy, R. \& Singh, V. (2009). Women Directors on Corporate Boards: A Review and Research Agenda. Corporate Governance : An International Review, 17(3), 320-337. http://dx.doi.org/10.1111/j.1467-868 3.2009.00742.x

Van der Walt, N. \& Ingley, C. (2003). Board Dynamics and the Influence of Professional Background, Gender and Ethnic Diversity of Directors. Corporate Governance: An International Review, 11(3), 218-234. http://dx.doi. org/10.1111/1467-8683.00320

Yermack, D. (1996). Higher Market Valuation of Companies with a Small Board of Directors. Journal of Financial Economics, 40(2), 185-211. http://dx.doi.org/10.1016/0304-405X(95)00844-5

\section{Notes}

Note 1. The part of the Nørby report containing the recommendations was published in the Handbook for Issuers on Copenhagen Stock Exchange in the same year.

Note 2. In Denmark, there are two types of auditors: State Authorized Public Accountants and Certified Public Accountants. The number of State Authorized Public Accountants is approximately 2000 and the number of Certified Public Accountants is approximately 3000. In comparison the entire Danish population is approximately 5.4 million people.

Note 3. The 7th Directive was implemented in the Danish Financial Statements Act in 1990.

Note 4. Specifically, $\$ 165$ (6) of the 2001 Financial Statements Act states that the two auditor requirement should remain in force for financial years beginning on or before 31 December 2004.

Note 5. The data was originally collected to map out the extent to which Danish companies comply with domestic and international corporate governance standards. In an effort to reduce errors and misunderstandings, the sample companies have been asked to read the tables with their own data and to point out incorrect information. A full list of attributes in the data set is available upon request to the authors.

Note 6. In this study we do not use 47 of the variables in the full dataset. Four of the variables are unrelated background variables such as "total audit fee" and "number of analysts following the company", while 32 are identified as conditioned variables (as an example: if the age of each board member is disclosed, conditioned variables would be "age of youngest board member"; "age of oldest board member" and "average age of board members"). The remaining 11 variables, which we do not use, are control variable (untabulated results are available).

Note 7. The corporate governance disclosure level is measured as the relative size (percentage) of a composite variable comprising 82 disclosure items. The measure is based on a simple addition of 82 items from the dataset including attributes covering the following factors: general CG-policy and information, information on strategy, mission, profits, expectations and risk management, investor relations policy (IR-policy), shareholder meeting procedures, board activity, board composition, compensation of management and board, management profile, auditor compensation and activity, and ownership structure and voting power.

Note 8. This dummy represents the exact formulation of international experience applied in the corporate governance recommendations of the Copenhagen Stock Exchange Committee on Corporate Governance, CSE (2005).

Note 9. One or more employee representatives are present in 73 of 100 companies with an average of 2.11 and a maximum of seven.

Note 10. The findings presented in table 4, panel $\mathrm{D}$ are based on a reduced model compared to the models behind panels A-C in that the international experience variable is excluded in order to avoid over- specification of the model for the audit committee decision. 
Table 1. Distribution of types of decision makers on boards

\begin{tabular}{|c|c|c|c|c|c|c|c|}
\hline & Foreigner & $\begin{array}{c}\text { International } \\
\text { experience }\end{array}$ & Women & $\begin{array}{c}\text { Accounting/ } \\
\text { finance } \\
\text { experience }\end{array}$ & $\begin{array}{c}\text { Sales/ } \\
\text { marketing } \\
\text { experience }\end{array}$ & $\begin{array}{c}\text { Industry } \\
\text { experience }\end{array}$ & Lawyer \\
\hline $\begin{array}{c}\text { Companies with } \\
\text { this type of } \\
\text { decision maker }\end{array}$ & 32 & 63 & 29 & 57 & 34 & 74 & 19 \\
\hline $\begin{array}{c}\text { Companies } \\
\text { without this type } \\
\text { of decision } \\
\text { maker }\end{array}$ & 68 & 37 & 71 & 43 & 66 & 26 & 81 \\
\hline Total & 100 & 100 & 100 & 100 & 100 & 100 & 100 \\
\hline
\end{tabular}

Table 2. Distribution of reporting and governance structure decisions

\begin{tabular}{|c|c|c|c|c|}
\hline & $\begin{array}{c}\text { IFRS } \\
\text { implementation }\end{array}$ & $\begin{array}{c}\text { CG disclosure } \\
\text { level }\end{array}$ & $\begin{array}{c}\text { From two to one } \\
\text { auditor }\end{array}$ & Audit committee \\
\hline $\begin{array}{c}\text { Companies with } \\
\text { differentiation decision }\end{array}$ & 15 & 23 & 55 & 12 \\
\hline $\begin{array}{c}\text { Companies without } \\
\text { differentiation decision }\end{array}$ & 85 & 77 & 45 & 88 \\
\hline Total & 100 & 100 & 100 & 100 \\
\hline
\end{tabular}

Note: The corporate governance disclosure level is measured as the relative size by a composite variable comprising 82 disclosure items. The number of companies with differentiation decision reflects the upper quartile of 100 companies. The mean is 0.49 and the standard deviation is 0.13 with a minimum of 0.27 and a maximum of 0.86

Table 3. Distribution of company specific control variables

\begin{tabular}{|c|c|c|c|}
\hline & Beta & ROIC 3 year average & Board size \\
\hline $\mathrm{N}$ & 100 & 100 & 7.71 \\
\hline Mean & 0.53 & 0.04 & 2.48 \\
\hline Std. Deviation & 0.38 & 0.21 & 2 \\
\hline Minimum & -0.07 & -1.08 & 18 \\
\hline Maximum & 1.76 & 0.63 & \\
\hline
\end{tabular}


Table 4. Logistic regression models for (H1) internationlisation effects

\begin{tabular}{|c|c|c|c|c|c|c|c|c|c|c|c|c|c|}
\hline \multicolumn{3}{|c|}{ Panel A: IFRS Implementation } & \multirow[b]{2}{*}{$\begin{array}{l}\text { Wald chi- } \\
\text { square }\end{array}$} & & & \multirow{3}{*}{\begin{tabular}{|c}
$\begin{array}{c}\text { Exp } \\
\text { (par. est.) }\end{array}$ \\
4.57 \\
\end{tabular}} & \multicolumn{2}{|c|}{ Panel B: CG disclosure } & \multirow[b]{2}{*}{$\begin{array}{c}\text { Standard } \\
\text { error }\end{array}$} & \multirow[b]{2}{*}{$\begin{array}{c}\text { Wald chi- } \\
\text { square }\end{array}$} & & & \multirow{3}{*}{$\begin{array}{c}\begin{array}{c}\text { Exp } \\
\text { (par. est.) }\end{array} \\
4.10\end{array}$} \\
\hline \multirow[b]{2}{*}{ Foreigner } & \multirow{2}{*}{\begin{tabular}{|c|}
$\begin{array}{c}\text { Parameter } \\
\text { estimate }\end{array}$ \\
1.52 \\
\end{tabular}} & \multirow{2}{*}{\begin{tabular}{|c|}
$\begin{array}{c}\text { Standard } \\
\text { error }\end{array}$ \\
0.73 \\
\end{tabular}} & & \multicolumn{2}{|c|}{ Sig.level } & & \multirow[b]{2}{*}{ Foreigner } & \multirow{2}{*}{\begin{tabular}{|c|}
$\begin{array}{c}\text { Parameter } \\
\text { estimate }\end{array}$ \\
1.41 \\
\end{tabular}} & & & \multicolumn{2}{|c|}{ Sig.level } & \\
\hline & & & 4.37 & 0.04 & * & & & & 0.65 & 4.66 & 0.03 & * & \\
\hline Int. experience & 1.01 & 1.01 & 1.00 & 0.32 & & 2.74 & Int. experience & 2.70 & 1.17 & 5.30 & 0.02 & * & 14.82 \\
\hline Beta & -0.68 & 0.94 & 0.52 & 0.47 & & 0.51 & Beta & -1.43 & 0.88 & 2.66 & 0.10 & & 0.24 \\
\hline ROIC 3 year avg. & -2.59 & 1.30 & 4.01 & 0.05 & $*$ & 0.07 & ROIC 3 year avg. & -0.06 & 1.45 & 0.00 & 0.97 & & 0.95 \\
\hline Board size & 0.11 & 0.13 & 0.66 & 0.42 & & 1.11 & Board size & 0.49 & 0.15 & 10.20 & 0.00 & $* * *$ & 1.63 \\
\hline Constant & -3.58 & 1.17 & 9.33 & 0.00 & $* *$ & 0.03 & Constant & -7.22 & 1.72 & 17.52 & 0.00 & $* * *$ & 0.00 \\
\hline -2 Log likelihood & 70.22 & & \multicolumn{2}{|c|}{ Model chi-square } & 14.32 & & -2 Log likelihood & 71.97 & & \multicolumn{2}{|c|}{ Model chi-square } & 35.89 & \\
\hline \multirow[t]{2}{*}{ Degrees of freedom } & 5 & & \multicolumn{2}{|c|}{ Significance } & 0.01 & $*$ & Degrees of freedom & 5 & & \multicolumn{2}{|c|}{ Significance } & 0.00 & $* * *$ \\
\hline & & & \multicolumn{2}{|c|}{ Nagelkerke R Square } & 0.23 & & & & & \multicolumn{2}{|c|}{ Nagelkerke R Square } & 0.46 & \\
\hline \multicolumn{3}{|c|}{ Panel C: From two to one auditor } & & & & & \multicolumn{2}{|c|}{ Panel D: Audit Committee } & & & & & \\
\hline & $\begin{array}{c}\text { Parameter } \\
\text { estimate }\end{array}$ & $\begin{array}{c}\text { Standard } \\
\text { error }\end{array}$ & $\begin{array}{c}\text { Wald chi- } \\
\text { square }\end{array}$ & \multicolumn{2}{|c|}{ Sig.level } & $\begin{array}{c}\text { Exp } \\
\text { (par. est.) }\end{array}$ & & $\begin{array}{c}\text { Parameter } \\
\text { estimate }\end{array}$ & $\begin{array}{c}\text { Standard } \\
\text { error }\end{array}$ & $\begin{array}{l}\text { Wald chi- } \\
\text { square }\end{array}$ & \multicolumn{2}{|c|}{ Sig.level } & $\begin{array}{c}\text { Exp } \\
\text { (par. est.) }\end{array}$ \\
\hline Foreigner & 0.51 & 0.51 & 1.00 & 0.32 & & 1.66 & Foreigner & 3.17 & 1.24 & 6.52 & 0.01 & $*$ & 23.74 \\
\hline Int. experience & -0.35 & 0.52 & 0.45 & 0.50 & & 0.71 & & & & & & & \\
\hline Beta & -0.21 & 0.62 & 0.12 & 0.73 & & 0.81 & Beta & 2.73 & 1.37 & 4.00 & 0.05 & $\dagger$ & 15.34 \\
\hline ROIC 3 year avg. & -0.32 & 1.05 & 0.09 & 0.76 & & 0.73 & ROIC 3 year avg. & -2.64 & 1.73 & 2.31 & 0.13 & & 0.07 \\
\hline Board size & -0.09 & 0.09 & 0.95 & 0.33 & & 0.92 & Board size & 0.73 & 0.24 & 9.11 & 0.00 & $* * *$ & 2.07 \\
\hline Constant & 1.06 & 0.73 & 2.12 & 0.15 & & 2.90 & Constant & -12.14 & 3.39 & 12.80 & 0.00 & $* * *$ & 0.00 \\
\hline -2 Log likelihood & 134.54 & & Model chi- & quare & 3.09 & & -2 Log likelihood & 36.22 & & Model chi- & uare & 37.17 & \\
\hline \multirow[t]{2}{*}{ Degrees of freedom } & 5 & & Significanc & & 0.69 & & Degrees of freedom & 4 & & Significanc & & 0.00 & $* * *$ \\
\hline & & & Nagelkerk & R Syuare & 0.04 & & & & & Nagelkerk & R Syuare & 0.60 & \\
\hline
\end{tabular}

Two-sided p-values ${ }^{* * *}<0.1 \%$; $* *<1 \% ; *<5 \% ; \uparrow<10 \%$

Dependent variables: (A) IFRS implementation; coded as 1 if the company decided for voluntary IFRS disclosure in the financial year 2004, and 0 otherwise, (B) CG disclosure level; coded as 1 if the corporate governance disclosure level belongs to the upper quartile for the 100 companies (high), and 0 otherwise (low), (C) From two auditors to one; coded as 1 if the company in the financial year 2005 changed from two auditors to one auditor, and 0 otherwise, and (D) Audit committee; coded as 1 if the company had established an audit committee, and 0 otherwise. Independent variables: International experience; coded as 1 if one or more members of the supervisory board have international experience such as board membership in foreign subsidiaries, and 0 otherwise, Foreigner; coded as 1 if the company has one or more foreigners at the supervisory board, and 0 otherwise, Beta measures the actual systematic risk attributed to the company, ROIC is measured as the three year average return on invested capital, and Board size is measured as the number of members on the supervisory board. 
Table 5. Logistic regression models for (H2) professional background effects

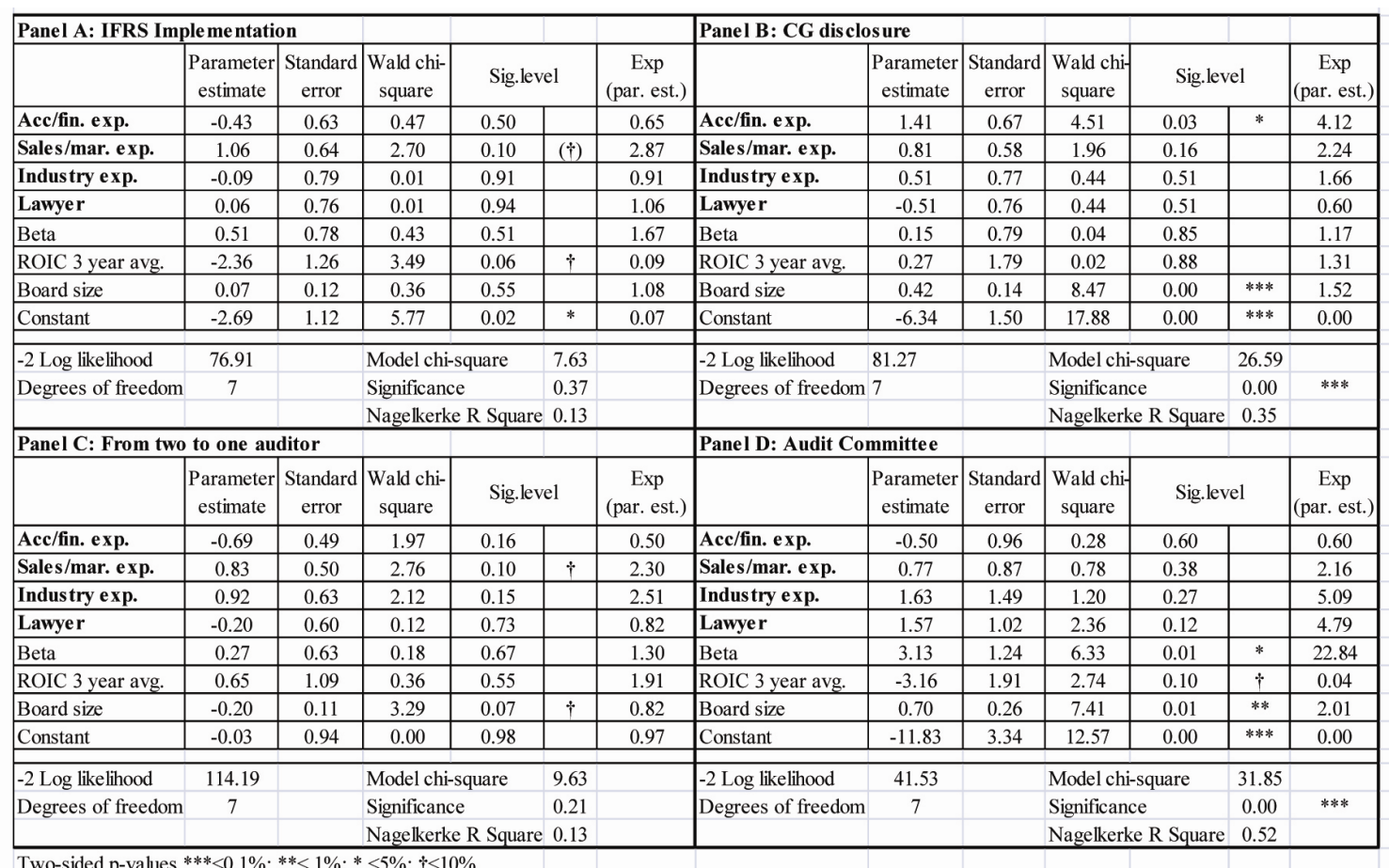

Two-sided p-values ***<0.1\%; $* *<1 \% ; *<5 \% ; \uparrow<10 \%$

Dependent variables: (A) IFRS implementation; coded as 1 if the company decided for voluntary IFRS disclosure in the financial year 2004, and 0 otherwise, (B) CG disclosure level; coded as 1 if the corporate governance disclosure level belongs to the upper quartile for the 100 companies (high), and 0 otherwise (low), (C) From two auditors to one; coded as 1 if the company in the financial year 2005 changed from two auditors to one auditor, and 0 otherwise, and (D) Audit committee; coded as 1 if the company had established an audit committee, and 0 otherwise. Independent variables : Accounting/finance experience; coded as 1 if one or more members of the supervisory board have professional accounting or finance experience, and 0 otherwise, Sales/marketing experience; coded as 1 if one or more members of the supervisory board have professional sales or marketing experience, and 0 otherwise, Industry experience; coded as 1 if one or more members of the supervisory board have specific industry experience related to the industry of the company, and 0 otherwise, Lawyer; coded as 1 if the company has one or more lawyer(s) at the supervisory board, and 0 otherwise, Beta measures the actual systematic risk attributed to the company, ROIC is measured as the three year average return on invested capital, and Board size is measured by the number of members on the supervisory board. 
Table 6. Logistic regression models for (H3) diversity effects

\begin{tabular}{|c|c|c|c|c|c|c|c|c|c|c|c|c|c|}
\hline \multicolumn{7}{|c|}{ Panel A: IFRS Imple me ntation } & \multicolumn{7}{|c|}{ Panel B: CG disclosure } \\
\hline & $\begin{array}{c}\text { Parameter } \\
\text { estimate }\end{array}$ & $\begin{array}{c}\text { Standard } \\
\text { error }\end{array}$ & $\begin{array}{l}\text { Wald chi- } \\
\text { square }\end{array}$ & \multicolumn{2}{|c|}{ Sig.level } & \multirow{2}{*}{\begin{tabular}{|c|}
$\begin{array}{c}\text { Exp } \\
\text { (par. est.) }\end{array}$ \\
1.69 \\
\end{tabular}} & \multirow{2}{*}{\multicolumn{2}{|c|}{\begin{tabular}{|l|c|} 
& $\begin{array}{c}\text { Parameter } \\
\text { estimate }\end{array}$ \\
$\begin{array}{l}\text { Diversity } \\
\text { (gender) }\end{array}$ & 1.32 \\
\end{tabular}}} & \multirow{2}{*}{\begin{tabular}{|c|}
$\begin{array}{c}\text { Standard } \\
\text { error }\end{array}$ \\
0.64 \\
\end{tabular}} & \multirow{2}{*}{\begin{tabular}{|c|}
$\begin{array}{c}\text { Wald chi } \\
\text { square }\end{array}$ \\
4.24 \\
\end{tabular}} & \multicolumn{2}{|c|}{ Sig.level } & \multirow{2}{*}{\begin{tabular}{|c|}
$\begin{array}{c}\text { Exp } \\
\text { (par. est.) }\end{array}$ \\
3.73 \\
\end{tabular}} \\
\hline \begin{tabular}{|l|} 
Diversity \\
(gender)
\end{tabular} & 0.53 & 0.62 & 0.72 & 0.40 & & & & & & & 0.04 & * & \\
\hline \begin{tabular}{|l|}
$\begin{array}{l}\text { Diversity } \\
\text { (composite) }\end{array}$ \\
\end{tabular} & 0.34 & 0.24 & 2.07 & 0.15 & & 1.41 & $\begin{array}{l}\text { Diversity } \\
\text { (composite) }\end{array}$ & 0.87 & 0.26 & 11.26 & 0.00 & $* * *$ & 2.38 \\
\hline \begin{tabular}{|l|}
$\begin{array}{l}\text { Diversity } \\
\text { (employee) }\end{array}$ \\
\end{tabular} & 1.23 & 0.96 & 1.62 & 0.20 & & 3.41 & \begin{tabular}{|l} 
Diversity \\
(e mployee)
\end{tabular} & 0.83 & 0.98 & 0.71 & 0.40 & & 2.28 \\
\hline Beta & 0.32 & 0.81 & 0.15 & 0.70 & & 1.37 & Beta & -0.22 & 0.81 & 0.07 & 0.79 & & 0.80 \\
\hline ROIC 3 year avg. & -2.57 & 1.27 & 4.11 & 0.04 & * & 0.08 & ROIC 3 year avg. & 0.38 & 1.87 & 0.04 & 0.84 & & 1.46 \\
\hline Board size & -0.04 & 0.14 & 0.08 & 0.78 & & 0.96 & Board size & 0.35 & 0.18 & 3.93 & 0.05 & * & 1.42 \\
\hline Constant & -3.59 & 1.18 & 9.21 & 0.00 & $* * *$ & 0.03 & Constant & -7.54 & 1.73 & 18.96 & 0.00 & $* * *$ & 0.00 \\
\hline -2 Log likelihood & 76.21 & & \multicolumn{2}{|c|}{ Model chi-square } & 8.33 & & -2 Log likelihood & 75.04 & & \multicolumn{2}{|c|}{ Model chi-square } & 32.82 & \\
\hline \multirow[t]{2}{*}{ Degrees of freedom } & 6 & & \multicolumn{2}{|c|}{ Significance } & 0.21 & & Degrees of freedom & 6 & & \multicolumn{2}{|c|}{ Significance } & 0.00 & **** \\
\hline & & & \multicolumn{2}{|c|}{ Nagelkerke R Square } & 0.14 & & & & & \multicolumn{2}{|c|}{ Nagelkerke R Square } & 0.42 & \\
\hline \multicolumn{3}{|c|}{ Panel C: From two to one auditor } & & & & & \multicolumn{2}{|c|}{ Panel D: Audit Committe e } & & & & & \\
\hline & $\begin{array}{c}\text { Parameter } \\
\text { estimate }\end{array}$ & $\begin{array}{c}\text { Standard } \\
\text { error }\end{array}$ & $\begin{array}{l}\text { Wald chi- } \\
\text { square }\end{array}$ & \multicolumn{2}{|c|}{ Sig.level } & $\begin{array}{c}\text { Exp } \\
\text { (par. est.) }\end{array} \mid$ & & $\begin{array}{l}\text { Parameter } \\
\text { estimate }\end{array}$ & $\begin{array}{c}\text { Standard } \\
\text { error }\end{array}$ & $\begin{array}{l}\text { Wald chif } \\
\text { square }\end{array}$ & \multicolumn{2}{|c|}{ Sig.level } & $\begin{array}{c}\text { Exp } \\
\text { (par. est.) }\end{array}$ \\
\hline \begin{tabular}{|l|}
$\begin{array}{l}\text { Diversity } \\
\text { (gender) }\end{array}$ \\
\end{tabular} & 0.17 & 0.50 & 0.12 & 0.73 & & 1.19 & $\begin{array}{l}\begin{array}{l}\text { Diversity } \\
\text { (gender) }\end{array} \\
\end{array}$ & 1.38 & 0.88 & 2.43 & 0.12 & & 3.97 \\
\hline \begin{tabular}{|l|}
$\begin{array}{l}\text { Diversity } \\
\text { (composite) }\end{array}$ \\
\end{tabular} & 0.22 & 0.17 & 1.62 & 0.20 & & 1.24 & \begin{tabular}{|l} 
Diversity \\
(composite)
\end{tabular} & 0.87 & 0.43 & 4.09 & 0.04 & * & 2.39 \\
\hline \begin{tabular}{|l|} 
Diversity \\
(employee)
\end{tabular} & 70 & 0.65 & 1.16 & 0.28 & & 2.01 & \begin{tabular}{|l|}
$\begin{array}{l}\text { Diversity } \\
\text { (e mployee) }\end{array}$ \\
\end{tabular} & -0.45 & 1.42 & 0.10 & 0.75 & & 0.64 \\
\hline Beta & 0.07 & 0.62 & 0.01 & 0.91 & & 1.08 & Beta & 2.82 & 1.20 & 5.51 & 0.02 & * & 16.79 \\
\hline ROIC 3 year avg. & 0.21 & 1.07 & 0.04 & 0.84 & & 1.23 & ROIC 3 year avg. & -2.97 & 1.95 & 2.31 & 0.13 & & 0.05 \\
\hline Board size & -0.26 & 0.14 & 3.55 & 0.06 & $\dagger$ & 0.77 & Board size & 0.62 & 0.29 & 4.49 & 0.03 & * & 1.87 \\
\hline Constant & 0.00 & 0.86 & 0.00 & 1.00 & & 1.00 & Constant & -11.96 & 3.34 & 12.84 & 0.00 & $* * *$ & 0.00 \\
\hline \begin{tabular}{|l|}
-2 Log likelihood \\
\end{tabular} & 118.97 & & \multicolumn{2}{|c|}{ Model chi-square } & 4.85 & & -2 Log likelihood & 39.92 & & \multicolumn{2}{|c|}{ Model chi-square } & 33.47 & \\
\hline Degrees of freedom & 6 & & \multicolumn{2}{|c|}{ Significance } & 0.56 & & Degrees of freedom & 6 & & \multicolumn{2}{|c|}{ Significance } & 0.00 & $* * *$ \\
\hline & & & Nagelkerke & R Square & 0.07 & & & & & Nagelkerk & R Square & 0.55 & \\
\hline
\end{tabular}

\section{Two-sided p-values $* * *<0.1 \%$; **< $<1 \% ; *<5 \% ; \uparrow<10 \%$}

Dependent variables: (A) IFRS implementation; coded as 1 if the company decided for voluntary IFRS disclosure in the financial year 2004 , and 0 otherwise, (B) CG disclosure level; coded as 1 if the corporate governance disclosure level belongs to the upper quartile for the 100 companies (high), and 0 otherwise (low), (C) From two auditors to one; coded as 1 if the company in the financial year 2005 changed from two auditors to one auditor, and 0 otherwise, and (D) Audit committee; coded as 1 if the company had established an audit committee, and 0 otherwise. Independent variables : Diversity (gender); coded as 1 if the company has one or more women at the supervisory board, and 0 otherwise, Diversity (employee); coded as 1 if the company has one or more employee representatives at the supervisory board, and 0 otherwise, Diversity (composite); a composite measure using a nominal scale from 0 to 5 with one point for each of the following board characteristics: international experience, accounting/finance experience, sales/marketing experience, industry experience, and lawyer, Beta measures the actual systematic risk attributed to the company, ROIC is measured as the three year average return on invested capital, and Board size is measured by the number of members on the supervisory board. 
Table 7. Reduced logistic regression models - all effects

\begin{tabular}{|c|c|c|c|c|c|c|c|c|c|c|c|c|c|}
\hline \multicolumn{3}{|c|}{ Panel A: IFRS Imple me ntation } & \multirow[b]{2}{*}{$\begin{array}{l}\text { Wald chi } \\
\text { square }\end{array}$} & \multirow{2}{*}{\multicolumn{2}{|c|}{ Sig.level }} & \multirow{3}{*}{$\begin{array}{c}\text { Exp } \\
\text { (par. est.) } \\
5.72 \\
\end{array}$} & \multicolumn{2}{|c|}{ Panel B: CG disclos ure } & \multirow[b]{2}{*}{$\begin{array}{c}\text { Standard } \\
\text { error }\end{array}$} & \multirow[b]{2}{*}{$\begin{array}{c}\text { Wald chi- } \\
\text { square }\end{array}$} & \multirow{2}{*}{\multicolumn{2}{|c|}{ Sig.level }} & \multirow[b]{2}{*}{$\begin{array}{c}\text { Exp } \\
\text { (par. est.) }\end{array}$} \\
\hline & $\begin{array}{c}\text { Parameter } \\
\text { estimate }\end{array}$ & $\begin{array}{c}\text { Standard } \\
\text { error }\end{array}$ & & & & & \multirow[b]{2}{*}{$\begin{array}{l}\text { H1(Int. } \\
\text { experie nce) }\end{array}$} & \multirow{2}{*}{\begin{tabular}{|c|}
$\begin{array}{c}\text { Paramete } \\
\text { r estimate }\end{array}$ \\
3.16 \\
\end{tabular}} & & & & & \\
\hline H1(Foreigner) & 1.74 & 0.68 & 6.55 & 0.01 & * & & & & 1.21 & 6.76 & 0.01 & $* *$ & 23.49 \\
\hline $\begin{array}{l}\text { H2(Sales/mar. } \\
\text { experience) }\end{array}$ & 0.63 & 0.65 & 0.96 & 0.33 & & 1.88 & $\begin{array}{l}\text { H2(Acc/fin.exp } \\
\text { erience) }\end{array}$ & 1.46 & 0.74 & 3.86 & 0.05 & $*$ & 4.32 \\
\hline H3 (-) & & & & & & & H3 (gender) & 1.59 & 0.68 & 5.46 & 0.02 & $*$ & 4.91 \\
\hline Beta & -0.30 & 0.94 & 0.10 & 0.75 & & 0.74 & Beta & -1.14 & 0.91 & 1.56 & 0.21 & & 0.32 \\
\hline ROIC 3 year avg. & -2.52 & 1.29 & 3.81 & 0.05 & $\dagger$ & 0.08 & ROIC 3 year avg & 0.12 & 1.76 & 0.00 & 0.94 & & 1.13 \\
\hline Board size & 0.11 & 0.13 & 0.69 & 0.41 & & 1.11 & Board size & 0.46 & 0.16 & 7.95 & 0.00 & $* * *$ & 1.59 \\
\hline Constant & -3.43 & 1.12 & 9.38 & 0.00 & $* * *$ & 0.03 & Constant & -8.45 & 2.01 & 17.67 & 0.00 & $* * *$ & 0.00 \\
\hline -2 Log likelihood & 70.31 & & Model chi & square & 14.23 & & -2 Log likelihood & 67.95 & & Model chi- & square & 39.90 & \\
\hline Degrees of freedom & 5 & & Significan & & 0.01 & $*$ & Degrees of freedo & 6 & & Significan & & 0.00 & $* * *$ \\
\hline & & & Nagelkerk & R Square & 0.23 & & & & & Nagelkerk & R Square & 0.50 & \\
\hline Panel C: From two & to one au & Iditor & & & & & Panel D: Audit C & Committee & & & & & \\
\hline & $\begin{array}{c}\text { Parameter } \\
\text { estimate }\end{array}$ & $\begin{array}{c}\text { Standard } \\
\text { error }\end{array}$ & $\begin{array}{l}\text { Wald chi } \\
\text { square }\end{array}$ & Sig.leve & & $\begin{array}{c}\text { Exp } \\
\text { (par. est.) }\end{array}$ & & $\begin{array}{l}\text { Paramete } \\
\text { r estimate }\end{array}$ & $\begin{array}{c}\text { Standard } \\
\text { error }\end{array}$ & $\begin{array}{l}\text { Wald chi- } \\
\text { square }\end{array}$ & Sig.leve & & $\begin{array}{c}\text { Exp } \\
\text { (par. est.) }\end{array}$ \\
\hline H1 (-) & & & & & & & H1(Foreigner) & 3.80 & 1.54 & 6.10 & 0.01 & * & 44.88 \\
\hline $\begin{array}{l}\text { H2(Sales/mar. } \\
\text { experience) }\end{array}$ & 0.89 & 0.47 & 3.60 & 0.06 & 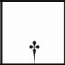 & 2.44 & H2 (-) & & & & & & \\
\hline H3 (-) & & & & & & & H3 (gender) & 1.67 & 1.03 & 2.65 & 0.10 & $(\dagger)$ & 5.33 \\
\hline Beta & 0.20 & 0.62 & 0.11 & 0.74 & & 1.22 & Beta & 3.50 & 1.68 & 4.32 & 0.04 & $*$ & 32.96 \\
\hline ROIC 3 year avg. & 0.30 & 1.04 & 0.08 & 0.77 & & 1.35 & ROIC 3 year avg & -2.29 & 1.90 & 1.46 & 0.23 & & 0.10 \\
\hline Board size & -0.19 & 0.11 & 3.21 & 0.07 & + & 0.82 & Board size & 0.76 & 0.28 & 7.33 & 0.01 & $* *$ & 2.13 \\
\hline Constant & 0.22 & 0.80 & 0.07 & 0.79 & & 1.24 & Constant & -14.11 & 4.40 & 10.31 & 0.00 & $* * *$ & 0.00 \\
\hline -2 Log likelihood & 117.71 & & Model chi & square & 6.11 & & -2 Log likelihood & 33.32 & & Model chi- & qquare & 40.06 & \\
\hline Degrees of freedom & 4 & & Significan & & 0.19 & & Degrees of freedo & 5 & & Significanc & & 0.00 & $* * *$ \\
\hline & & & Nagelkerk & R Square & 0.08 & & & & & Nagelkerk & R Square & 0.63 & \\
\hline
\end{tabular}

Two-sided p-values $* * *<0.1 \% ; * *<1 \% ; *<5 \% ; \uparrow<10 \%$

Dependent variables: ((A) IFRS implementation; coded as 1 if the company decided for voluntary IFRS disclosure in the financial year 2004, and 0 otherwise, (B) CG disclosure level; coded as 1 if the corporate governance disclosure level belongs to the upper quartile for the 100 companies (high), and 0 otherwise (low), (C) From two auditors to one; coded as 1 if the company in the financial year 2005 changed from two auditors to one auditor, and 0 otherwise, and (D) Audit committee; coded as 1 if the company had established an audit committee, and 0 otherwise. Independent variables: International experience; coded as 1 if one or more members of the supervisory board have international experience such as board membership in foreign subsidiaries, and 0 otherwise, Foreigner; coded as 1 if the company has one or more foreigners at the supervisory board, and 0 otherwise, Accounting/finance experience; coded as 1 if one or more members of the supervisory board have professional accounting or finance experience, and 0 otherwise, Sales/marketing experience; coded as 1 if one or more members of the supervisory board have professional sales or marketing experience, and 0 otherwise, Diversity (gender); coded as 1 if the company has one or more women at the supervisory board, and 0 otherwise, Beta measures the actual systematic risk attributed to the company, ROIC is measured as the three year average return on invested capital, and Board size is measured by the number of members on the supervisory board. 


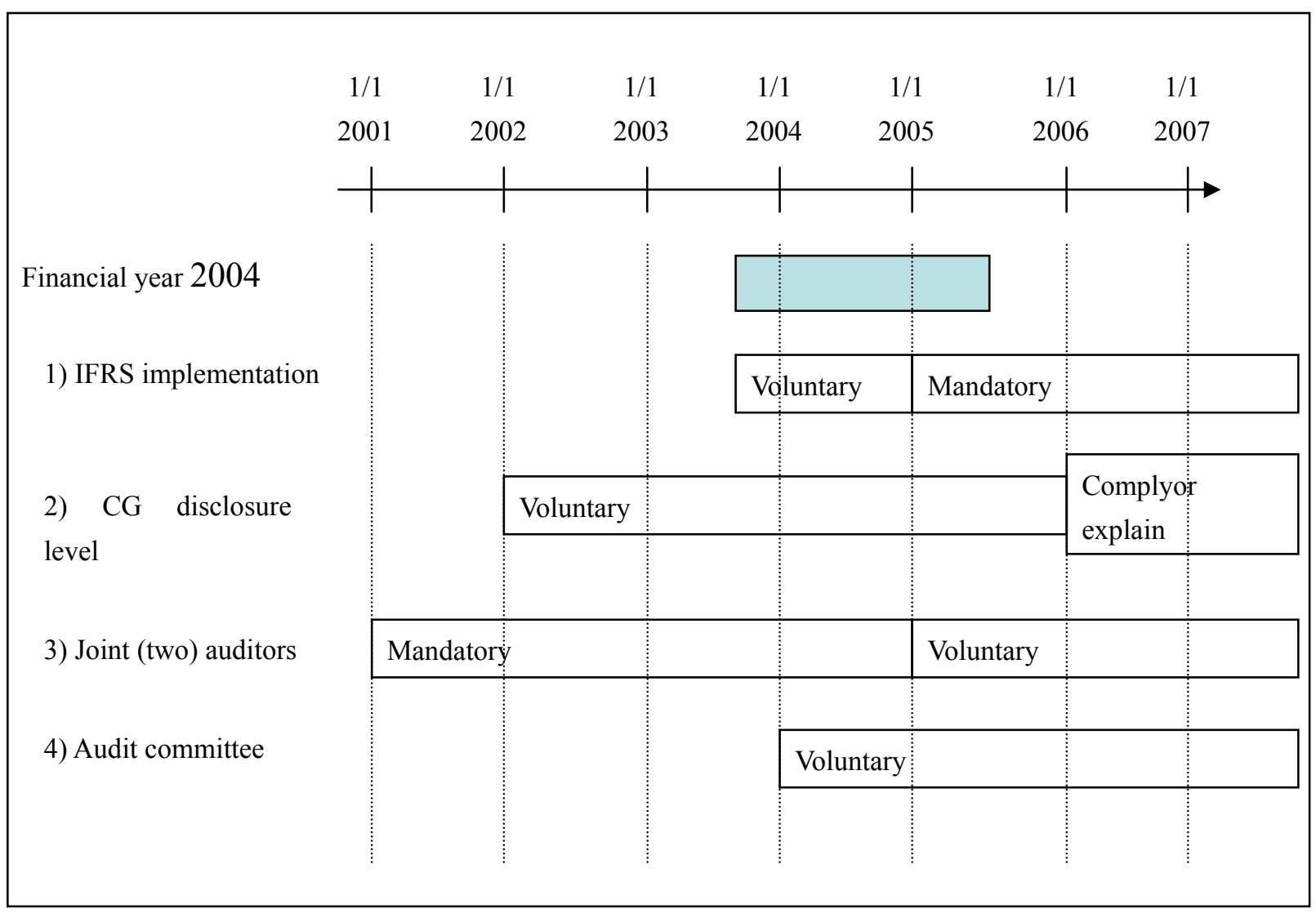

Figure 1. Overview of regulatory requirements in relation to four differentiation decisions

Note: 20 of 100 companies did not use the calendar year as their financial year for 2004 . The earliest financial year was Sep. $1^{\text {st }} 2003$ to Aug. $30^{\text {th }} 2004$. The latest financial year was July $1^{\text {st }} 2004$ to June $30^{\text {th }} 2005$. 